\title{
The development of the Old High German umlauted vowels and the reflex of New High German / $\varepsilon$ :/ in Present Standard German
}

\author{
Fausto Cercignani (Milano)
}

\begin{abstract}
A critical reconstruction of the development of the Old High German umlauted vowels sheds light on the phonological history of various vocalic phonemes and in particular of $/ \varepsilon /$ and $/ \mathrm{e} /$ as well as of $/ \varepsilon: /$ and /e:/. The changes that affected the two pairs led to different results in the New High German Schriftsprache, in which today's / $\varepsilon$ :/ beside /e:/ in words with "long ä" (e. g. spät) is not an artificial vowel based on the spelling, but a historical variant with a phonological history behind it.
\end{abstract}

\section{$1 \quad$ Introduction}

It is a well-known fact that the stressed vowels of Old High German underwent distance assimilation changes generally known as umlauts which were triggered off by specific factors in the next syllable.

The pre-literary Old High German vowels affected by $i$-umlaut were [a], [a:], [o], [o:], [u], [u:], [iu], [uo], [ou] before $i$-sounds ([i], [i:], [j]) in the next syllable. The products of the relevant changes were (approximately) [æ] and [e], [æ:], [ø], [ø:], [y], [y:], [iy], [уø], [øу].

With regard to the $i$-umlaut of /a/, the traditional terms "primary umlaut" and "secondary um-

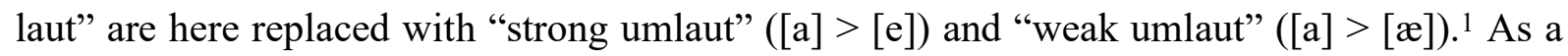
result of the $i$-umlaut of /a/, Old High German came to exhibit three types of short $e$-sounds. ${ }^{2}$ This state of affairs is not surprising, especially if one considers that three types of short $e$ sounds are reported from Modern Swiss German (cf. Russ 1990: 369), where their distribution is, however, somewhat different. In the line of development that led to Present Standard German, the three vowels were later reduced to one, the antecedent of today's / $\varepsilon /$ (see below, 2.1.A).

\footnotetext{
${ }^{1}$ The traditional terms "primary umlaut" and "secondary umlaut" were devised to indicate that the stage [e] was reached in Old High German and that the stage [æ] belongs to Middle High German. However, $i$-umlaut must have affected all vowels and diphthongs in the oldest period of the language, since the $i$-sounds in unstressed or weakly stressed syllables changed or disappeared by the end of the Old High German period at the latest: [i] and [i:] were weakened to approximately [ə], while [j] disappeared even earlier (cf. Braune/Heidermanns 2018: §54, § 118, fn. 2).

${ }^{2}$ For different views on this point cf. Simmler (2000: 1325).
} 
The Old High German $i$-umlauts may be summarized as follows: ${ }^{3}$

- $\quad$ split of /a/ into /a/, /æ/ and /ẹ/4, with subsequent lowering of /ẹ// to /e/ and, consequently, of PGmc /e/ to /E/; examples: 5 /a/ in slahta 'Schlacht' vs. /æ/ in [gi]slahti 'Geschlecht', /a/ in balg (< ‘Balg' vs. /ệ/ in [ir]belgen (<*balgjan) '(obsolete) bälgen'6; Gmc /e/ in belgan '(obsolete) belgen'7.

- $\quad$ split of /a:/ into /a:/ and /æ:/, as in gāha (MHG gāhe; cf. DGW s. v. gach, f.) 'Eile' (obsolete 'Gach') and gāhi 'jäh, jähe' (MHG gahe).

- split of /o/ into /o/ and /ø/, as in holo (MHG hole, hol; cf. DGW s. v. hohle) 'Loch' (obsolete 'Hohle') and holī (MHG höle, höl) 'Höhle'.

- split of /o:/ into /o:/ and /ø:/, as in scōno (MHG schōne) 'schon' and scōni (MHG schöne) 'schön'.

- $\quad$ split of /u/ into /u/ and /y/, as in brunno (MHG brunne; cf. DGW s. v. brunne) 'Brunnen' (obsolete 'Brunne') and brunnī (MHG brünne) 'Brünne'.

- $\quad$ split of /u:/ into /u:/ and /y:/, as in (h)lütèn (MHG lüten) 'lauten' and (h)lüten, (h)liuten (MHG liuten) 'läuten'?.

- $\quad$ split of /iu/ into /iu/ and /iy/, as in hiuru (MHG hiure = hüre) 'heuer' and hiuri (MHG [ge]hiure $=$ hüre) 'geheuer, einfältig'. 10

- $\quad$ split of/ou/ into /ou/ and/øy/, as in houwa (MHG houwe) 'Haue' and houwi (MHG höuwe) 'Heu'.

- $\quad$ split of /uo/ into /uo/ and /yø/, as in suozo (MHG sueze, adv.) ${ }^{11}$ and suozi (MHG süeze) 'süß'.

\section{The subsequent development of the umlauted vowels}

The changes that modified the Middle High German and (early) New High German vocalic systems obviously affected also the umlauted vowels.

In what follows these changes will be critically discussed with a view to reconstructing the line of development that led to Present Standard German. In this context, due attention will be given to different types of speech, to phonological variants and to relative chronology, but the peculiarities of different areas at different times will be taken into account only where necessary.

\footnotetext{
${ }^{3}$ On the phonemicization of the Old High German umlauted vowels cf. Cercignani (forthcoming).

${ }^{4}$ The symbol [ë] stands for a slightly centralized [ẹ].

${ }^{5}$ When not otherwise stated, all the examples cited in this article are taken from AWB; Köbler (2014) and MWB.

${ }^{6}$ Cf. DWB s. v. bälgen (to flay or skin), which has $\langle\ddot{a}\rangle$ instead of $\langle\mathrm{e}\rangle$ on the analogy of Balg.

${ }^{7}$ Cf. DWB s. v. belgen (to quarrel or wrangle). Cf. the new formation balgen from Balg.

${ }^{8}$ The form holi (originally *hulī- > MHG hüle) appears to derive from a new formation *holī- on the analogy of *hola- $<$ *hula- (OHG hol). Both MHG höle and hole (*hulō-) underwent open syllable lengthening.

${ }^{9}$ The 〈ä〉 in läuten is due to the analogy of the 〈a〉 in laut, the historical spelling of OHG MHG liuten being leuten (cf. DWB s. v. läuten), which has $\langle\mathrm{eu}\rangle$ representing earlier /øy/ (/y:/ >/yy/ >/øy/ > /œy/ > /or/). Cf. Leute (OHG liuti, MHG liute), with /y:/ from /iy/ (umlauted /iu/), and heute (OHG hiutu, MHG hiute) with /y:/ from /iu/.

${ }^{10}$ Soon after its rise, the phoneme /iy/generally merged with /y:/ from umlauted /u:/. Before the end of the Old High German period a similar merger affected /iu/ in vast areas of Alemannic and Franconian (cf. Wiesinger 1970: 233f.).

${ }^{11}$ Cf. also fruoi (MHG vrüeje) 'früh’ vs. fruo (MHG frue, adj.) - KSW: § A 154.
} 


\subsection{The subsequent development of the $e$-vowels}

The changes affecting the various $e$-vowels are not always easy to reconstruct (FNHDG: $\S \mathrm{L}$ $12,19,20)$, but the following is a reasonable explanation of the developments that led to the simplification of the short vowel system, though not invariably to that of the long vowel system.

(A) The first change to be considered here is the raising of $/ \mathfrak{a} /$ (the product of the weak $i$-umlaut of $/ \mathrm{a} /$ ) to $/ \varepsilon /$ in late Old High German or early Middle High German. This shift of the short vowel resulted in a merger of /æ/, as in MHG geslähte (OHG gislahti) 'Geschlecht', with the reflex of $\mathrm{OHG} / \varepsilon /$, as in $\mathrm{MHG}$ recht (OHG recht) 'Recht'. The raising of /æ/ to /E/ must have occurred after lengthening (chiefly in an open syllable and before $/ \mathrm{r} / \mathrm{plus}$ consonant), since the lengthened reflex of $\mathrm{OHG} / æ /$ merged only with $/ \varepsilon$ :/ (as in $\ddot{A} h r e$ ), whereas the lengthened reflex of OHG / $/ \varepsilon /$ merged with either $/ \varepsilon$ :/ or /e:/ (see 3, below).

The three short $e$-vowels of the Old High German period were thus reduced to two, until the new $/ \varepsilon /$ and the pre-existing /e/ (the product of the strong $i$-umlaut of $/ \mathrm{a} /$ ) merged in a single phoneme, at least in certain types of speech belonging to the Central German and Upper German (East Franconian) areas. As a result of this change words with $/ \varepsilon /$, such as MHG geslähte, geslehte (OHG gislahti) 'Geschlecht' and MHG recht (OHG recht $<*$ rehta-) 'Recht', as well as words with /e/, such as MHG feste (OHG festi <*fastja-) 'fest', came to exhibit the same phoneme, the antecedent of Present Standard German $/ \varepsilon /$.

However, in other types of speech belonging to the Upper (but in part also to the Central) German area the distinction between the new $/ \varepsilon /$ and the older /e/ was preserved at least for some time, so that lengthening resulted in variants with either / $\varepsilon: /$ or /e:/. Both types eventually found their way into the New High German "Schriftsprache". Examples: Bär, währen, etc., leben, Wert, etc. (see 3, below). A parallel regional variation came into being as a result of the changes affecting the long vowel /æ:/.

(B) The long vowel /æ:/ (the product of the $i$-umlaut of /a:/) was similarly raised to $/ \varepsilon: /$, as in MHG spcete (OHG spāti) 'spät'. Moreover, in certain types of speech belonging to the Central German and Upper German (East Franconian) areas (Reichmann 2000: 1630) the resulting / $:$ :/ and the reflex of OHG /e:/ merged in a single phoneme /e:/. As a result of this change, words with /ع:/, such as MHG spcete (OHG spāti) 'spät', and words with /e:/, such as MHG mēr[o] (OHG mēr $[o])<*$ maizō) 'mehr', came to exhibit a new phoneme /e:/.

However, in other types of speech belonging to the Upper (but in part also to the Central) German area the product of the $i$-umlaut of /a:/ (as in MHG spcete, OHG spāti 'spät') preserved its identity and the distinction between / $\varepsilon: /$ and /e:/ made its way into the New High German "Schriftsprache" as early as the 16th century. This development was certainly encouraged by morphological/etymological considerations (FNHDG: § L 20), but would have been impossible without the linguistic levelling between regional varieties (see 3, below) which led to the coexistence in Present Standard German of words in which MHG $/ \varepsilon$ :/ is represented either by $/ \varepsilon: /$ (as in $z \ddot{a} h)$ or by /e:/ (as in leer).

\subsection{The subsequent development of the other umlauted vowels}

Most of the changes presented below belong to Middle High German, but those related to the diphthong /iy/ occurred before the end of the Old High German period. 
(A) The developments related to the diphthong /iy/ present peculiarities that can be reconstructed chiefly by having recourse to the evidence of modern dialects (cf. Wiesinger 1970: 233f.). Soon after its rise, the phoneme /iy/ generally merged with /y:/ from umlauted /u:/. Before the end of the Old High German period a similar merger affected /iu/ in vast areas of Alemannic and Franconian, whereas in Bavarian, Swabian and southern parts of High Alemannic /iu/ was to a certain extent retained, because in those areas 1) the $i$-umlaut of /iu/ appears to have occurred only before an intervening dental consonant (as in liuti 'Leute'), and 2) the retained /iu/ did not merge with/y:/, so that a form like diup (Old Franconian diop, MHG diep) 'Dieb' retained a diphthongal pronunciation (MHG diup).

Present Standard German reflects the generalized merger of /iu/ and /iy/ with /y:/ (later/yy/ > /øy/ > /œy/ > /っI/), as in heute (OHG hiutu, MHG hiute) and Leute (OHG liuti, MHG liute). However, in some cases we find /i:/ for expected /oI/, as in Tiefe (OHG tiufi, MHG tiufe) beside Teufe (the mining term), since the former variant is an analogical reformation after tief (OHG tiof, MHG tief).

(B) The other changes affecting the umlauted vowels belong to the Middle High German period, but are often assigned to New High German because their products eventually found their way into the New High German "Schriftsprache". ${ }^{12}$

The first change to be considered here affected the diphthong /yø/, which became /yə/ and then /y:/ as part of the early Middle High German monophthongization that involved also /uo/ > /uə/ $>/ \mathrm{u}: /$ and /io/ > /iə/ > /i:/. ${ }^{13}$ Examples: MHG füeze (OHG fuozzi) > NHG Füße; MHG fuoz $\left(\mathrm{OHG}\right.$ fuoz) $>$ NHG Fuß; MHG tier (OHG tior) $>$ NHG Tier. ${ }^{14}$

These monophthongizations did not result in mergers with the older monophthongs $/ y: /$, as in MHG liute (OHG liuti) 'Leute', MHG liuten (OHG lüten <*hlüdjan-) 'läuten', /u:/, as in MHG $h \bar{u} s$ (OHG hiss) 'Haus', and /i:/, as in MHG wīb (OHG wīb) 'Weib', apparently because these vowels were already slightly diphthongized (see below).

The new monophthongal phonemes shared with other vowels the Middle High German irregular shortening before certain consonant and consonant clusters: /y:/ > /y/, as in müeter $>$ NHG Mütter, /u:/ > /u/, as in fuoter > NHG Futter, /i:/ > /i/, as in lieht > NHG Licht. This change affected also umlauted long vowels, as in, for example, ahten ( $<*$ anhtjan) $>$ NHG ächten, which exhibits shortening of /æ:/ to /æ/.

\footnotetext{
${ }^{12}$ Cf. Wiesinger 2003: 2442 ("New High German monophthongization"), 2452 ("Shortening”), 2445 ("New High German diphthongization"), 2452 ("Lengthening"), 2449 ("Unrounding and Rounding"), 2450 ("Lowering and Raising"). Wolf (2000: 1533) observes that the monophthongizations and diphthongizations in question could be subsumed under the term 'Early New High German Vowel Shift' ("frnhd. Vokalverschiebung").

${ }^{13}$ For a detailed study of the problems connected with these monophthongizations in the Central German dialects cf. Klein 2021.

14 This monophthongization affected also /iə/ from PGmc secondary /ẹ:/ (/e $\left.\overline{\mathrm{e}}^{2} /\right)$, as in MHG hier (OHG hēr, hear, hiar) > NHG hier.
} 
Moreover, it was with these new monophthongs that the corresponding products of the Middle High German irregular lengthening, mostly in an open syllable, ${ }^{15}$ coalesced: $/ \mathrm{y} />/ \mathrm{y}: /$, as in zügel $(<*$ tugila-) $>$ NHG Zügel; /u/ > /u:/, as in tugent $(<*$ dugunpi-) $>$ NHG Tugend; /i/ > /i:/, as in rise $(<*$ wrisja- $)>$ NHG Riese. This lengthening affected all the Middle High German short vowels, ${ }^{16}$ including the other short products of $i$-umlaut: /e/ $>/ \mathrm{e}: /$, as in gegen $(<*$ gagini) $>$ NHG gegen and /ø/ > /ø:/, as in öl[e] $(*$ oli $<\mathrm{L}$ oleum $)>$ NHG Öl.

The fact that the above monophthongizations did not result in mergers with the older monophthongs has been explained with the assumption of a lower point of articulation for the new monophthongs (e. g.: /ụ:/ vs. /u:/ - Moulton 1961: 32; Wiesinger 2003: 2443), but the early Middle High German diphthongization of the older monophthongs speaks for the assumption that these were already slightly diphthongized: /ri/, later/ei/ > /عI/>/ai/, as in NHG Weib; /Yy/ later /øy/ > /œy/ > /or/, as in NHG Leute, läuten; / u/ later/ou/ > /ov/ > /av/, as in NHG Haus. ${ }^{17}$ This diphthongization eventually resulted in mergers with the older diphthongs /ei/, /øy/, and /ou/ exemplified by MHG bein (OHG bein) 'Bein', MHG löufet (OHG loufit) '(er) läuft', and MHG ouge (OHG ouga) 'Auge'.

In some types of regional speech the products of umlaut were unrounded and some of the new forms found their way into the New High German "Schriftsprache": /y/ > /i/, as in MHG küssen $>$ Kissen; /y:/ > /i:/ (> /ei/), as in MHG spriuzen > spreizen;/øy/ > /ei/, as in MHG slöufe > Schleife.

In other types of regional speech, front vowels were rounded and some of the new "umlauted" forms found their way into the New High German "Schriftsprache": /i/ > /y/, as in MHG finf > fünf; /e/ > /œ/, as in MHG leffel > Löffel and (with lengthening in an open syllable) MHG lewe $>$ Löwe.

The regional lowering of $/ \mathrm{u} /$ and $/ \mathrm{y} /$ to $/ \mathrm{o} /$ and $/ \mathfrak{m} /$ before nasals was accepted in the New High German "Schriftsprache" in a few instances with earlier /y/, such as gönnen (OHG giunnan), können (OHG kunnan, MHG kunnen, künnen), and König (OHG kuning), as well as, of course, in a few instances with earlier/u/, such as Sonne (OHG sunna), kommen (OHG kuman), Sohn (OHG sunu), etc. ${ }^{18}$

\section{The reflex of NHG / $\varepsilon$ :/ in Present Standard German (PSG)}

Today's / $\varepsilon$ :/ in words with “long $\ddot{a}$ ” has often been regarded as a problematic vowel. Generally speaking, the distinction between / $\varepsilon: /$ and /e:/ is more frequent in the South than in the North. Northern speakers use $/ \varepsilon$ :/ instead of /e:/ only in formal speech and to distinguish such pairs as gebe and gäbe, as well as of course for the name of the letter $\langle\ddot{\partial}\rangle$. Southern speakers normally

\footnotetext{
${ }^{15}$ For lengthening in monosyllables before final /r/ (OHG furi 'für'), before /r/ plus dental (OHG pfarifrit $>$ MHG pfärt 'Pferd'), and in monosyllables with closed syllable on the analogy of inflected forms (MHG tür - türe 'Tür - Türen') cf. Paul/Klein (2007: 82f).

${ }^{16}$ Lengthening of short vowels in an open syllable is a peculiarity of both High and Low German dialects (cf. Schirmunski 1962: 183).

${ }^{17}$ For a review of the questions related to these changes cf. Penzl (1974: 345-357).

${ }^{18} \mathrm{Cf}$. the regional raising of /a:/ to /o:/ accepted in such words as Brodem (OHG brädam), Monat (OHG mānōd), wo (OHG wār), Odem ( Atem, OHG ātum), etc.
} 
keep /ع:/ and /e:/ apart, but the distribution of the two phonemes in regional speech does not always agree with that of Standard German.

The phonemic status of today's / $\varepsilon$ :/ cannot be denied (despite Szulc 1969: 74f.), since the distinction is found in such pairs as Ähre-Ehre, Bären-Beeren, gäbe-gebe, jäh-je, SäleSeele, schämen - Schemen, etc.

The difficulties ascribed to this phoneme are partially due to the circumstance that the triplet $\mid \varepsilon /-/ \varepsilon: /-/ \mathrm{e}: /$ is an exception in the vocalic system of Present Standard German:

$$
\begin{aligned}
& \text { /i:/ - /I/ } \\
& \text { /y:/ - /y/ } \\
& \text { /u:/ - /v/ } \\
& \text { /e:/ - | }: /-\mid \varepsilon / \\
& \text { /ø/-/œ/ } \\
& \text { /o:/ - /0/ } \\
& \text { /a:/ - /a/ }
\end{aligned}
$$

The preoccupation with symmetry has led to endless discussions on how to interpret this "anomaly", and some scholars have had recourse to apparently decisive solutions. Thus Becker (2012: 38) interprets / $\varepsilon: /$ as /æ:/. This is of course quite legitimate, since "long $\ddot{a}$ " varies between [ع:] and [æ:], but the fact remains that $/ \varepsilon$ :/ has no counterpart of its own, since $/ \varepsilon /$ is also the counterpart of /e:/.19 Sanders (1972: 58) suggests that / $\varepsilon: /$ and /e:/ may be subsumed under a "socio-archiphoneme" / $\overline{\mathrm{E}} /$. But such a solution, though interesting, is of little help when it comes to describing the speech of those who keep / $\varepsilon$ :/ and /e:/ apart. The fact is that vocalic systems (and phonemic systems in general) cannot be expected to be always symmetric. They should reflect reality, not abstract models.

In other cases, a too rigid interpretation of the development of the German $e$-vowels has resulted in a substantial exclusion of / $\varepsilon$ :/ from the phonological history of the German vocalic system. Thus, having considered a single line of development from an undifferentiated East Middle German to a type of New High German similar to today's standard language, Moulton (1961: $34 \mathrm{f}$.) dismissed $/ \varepsilon$ :/ as a spelling-pronunciation vowel with no real history behind it. ${ }^{20}$ This view has found numerous followers, Paul/Klein (2007: 64) and Garbe (2000: 1768) among others. The latter states bluntly that /ä/ is diachronically and phonologically unwarranted ("/ $/ \ddot{\mathrm{A}} / \mathrm{ist}$ diachronisch-phonologisch nicht motiviert").

\footnotetext{
${ }^{19}$ Cf. Dudenredaktion 2009: 35, where the opposition between "long" and "short" vowels is interpreted as an opposition between "tense" and "lax", so that the triplet in question is presented as $/ \mathrm{e} /-/ \mathfrak{x} /-/ \varepsilon /$.

20 "[...] das $\bar{a}$ von lägen, sähe, jäh. Kein solcher Vokal ist in unserer historischen Behandlung des Vokalsystems aufgetaucht [...] Wir schließen unsere Geschichte des nhd. Vokalsystems also mit einem Phonem, das keine 'Geschichte' im gewöhnlichen Sinne des Wortes hat, sondern lediglich ein papiernes, oft prekäres, aber immerhin brauchbares Dasein fristet" (Moulton 1961: 34f.).
} 
Of course, even spelling-pronunciations have their own history and the influence of orthography on pronunciation is a well-known fact. However, things are not as simple as that and the available evidence with regard to $/ \varepsilon$ :/ should be carefully analysed.

The orthography of the Middle and early New High German period is ambiguous and therefore unreliable as evidence of a merger of / $\varepsilon$ :/ to identity with /e:/. The traditional spelling for $/ \varepsilon$ :/ was $\langle\mathrm{e}\rangle$, while the ligature $\langle\mathfrak{e}\rangle$ and the combined digraph $\langle\mathrm{e}\rangle$ occurred only in Bavarian and East Alemannic manuscripts (cf. Paul/Klein 2007: 97).

Rhymes cannot be used to ascertain generalized mergers. If corroborated by other evidence, they may at most reflect a merger in specific types of speech, provided that due regard is given to traditional and inexact rhymes. Moreover, poets may be inclined to rely on variant pronunciations if they find them useful for their rhymes.

Etymology is on the other hand reliable in most cases and can contribute to explain the present distribution of / $\varepsilon$ :/ ("long $\ddot{a}$ ") and /e:/ ("long $e$ "). A useful analysis of the available material should carefully distinguish instances in which the relevant vowel is the result of phonological changes from forms in which it is analogical, as well as from ambiguous and therefore inconclusive cases.

The available material may be presented as follows:

- Items with OHG MHG /e:/ seem to exhibit only today's /e:/. Examples: Ehre (OHG êra), mehr (OHG mèr[o]), See (OHG sēo), Zeh[e] (OHG zēha, MHG zē[he]), etc.

- Items with the strong $i$-umlaut of $\mathrm{OHG} / \mathrm{a} /$ to /e/ and subsequent lengthening to /e:/ seem to exhibit only today's /e:/. Examples: Beere (OHG beri, MHG ber[e]), Heer (OHG heri, MHG her), jener (OHG jenēr, MHG jener), wehren (OHG werien, MHG weren), etc.

- In plural forms like Schläge (OHG slegi), Zähne (OHG zeni), and Räder (OHG redir) the vowel /e:/ by lengthening of umlaut-/e/ has been replaced by $/ \varepsilon$ :/ as a generalized marker of the plural number in words with /a:/ in the singular: Schlag (OHG slag), Zahn (OHG zan), Rad (OHG rad). Cf. Räte (OHG rāti, MHG rate) - Rat (OHG MHG rāt), which exhibits a regularly developed / $\varepsilon$ :/.

- In infinitives like nähren (OHG nerien), quälen (OHG quel[l]en <*kwaljan), schälen (OHG skel[l]en < *skalljan), zählen (OHG zel[l]en <*taljan), etc. the older /e:/ by lengthening of umlaut-/e/ has been replaced by / $\varepsilon$ :/ on the analogy of related forms with /a:/ (original or by lengthening), such as Nahrung (OHG narunga), Qual (OHG quāla), Schale (OHG skala), Zahl (OHG zala), etc.

- In verbal forms like (du) färst (OHG ferist, MHG ferest) the older /e:/ by lengthening of umlaut-/e/ has been replaced by / $\varepsilon$ :/ on the analogy of related forms with /a:/ (fahren, OHG faran, MHG faren > fären).

- The word Fährte 'Wildspur' derives from inflected forms of Fahrt (OHG fart, gen. dat. ferti, MHG ferte) and its /e:/ by lengthening of umlaut-/e/ has been replaced by / $\varepsilon$ :/ on the analogy of Fahrt (MHG fart $>$ fārt), which originally meant also 'animal track'. ${ }^{21}$

\footnotetext{
${ }^{21}$ Cf. DWB s. v. Fahrt (6) and Fährte (zu der Fährte, ein Zeichen der Fährte, etc. > nom. acc. Fährte).
} 
- In the word Käfig (OHG kevia < L cavea; cf. Kluge/Seebold: s. v. Käfig) MHG /e:/ by lengthening of /e/ (kevje > kevige) has been replaced by $/ \varepsilon: /$ representing NHG "long $\ddot{a}$ " in a variant remodelled on L cavea.

- The doublet schmäler $\sim$ schmaler, which seems to be the only comparative with $/ \mathrm{a} />$ /a:/ in the positive (OHG smal- > MHG smāl), reflects the original variation between the endings -iro and -ôro, which is typical of Old High German comparatives. The variant schmaler preserves the original vowel (OHG smalōro, MHG smaler), whereas the umlauted variant reflects the replacement of /e:/ (OHG smeliro, MHG smeler > sméler) by / $\varepsilon$ :/ on the analogy of other comparatives, $i$-umlaut being frequent, though not generalized, in words with $\langle a\rangle$ in the positive. ${ }^{22}$ Relevant instances are the unique näher - nah, with "long $\ddot{a}-a$ " (see below), and various cases with "short $\ddot{a}-a$ ", such as älter - alt (OHG eltiro - alt), kälter (OHG keltiro - kalt), länger - lang (OHG lengiro - lang), etc., in which $\langle\mathrm{e}\rangle$ has been replaced by $\langle a ̈\rangle$.

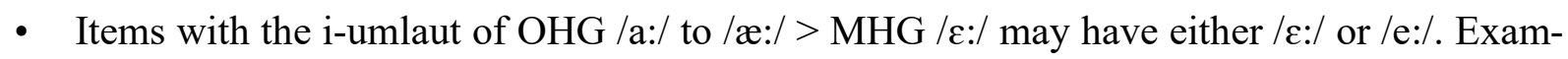
ples:

- Items with /ع:/. Mär (OHG māri, MHG mare), säen (OHG sājan, sāen, MHG sajen), träge (OHG trāgi, MHG traege), zäh (OHG zāhi, MHG zceh[e]); (er) rät (OHG rātit, MHG ratet/rcet), (er) näme (OHG nāmī, MHG næeme), (ich) wäre (OHG wāri, MHG woere), etc.

- The form näher, which seems to be a unique instance, cannot be adduced to show / $\varepsilon$ :/ as an additional marker of the comparative in adjectives with /a:/ in the positive (OHG $n \bar{a} h$ ), since its vowel is regularly developed from the Old High German variant nāhiro beside $n \bar{a} h \bar{o} r o$, the variation $\mathrm{OHG}$-ōro $\sim$-iro being typical of all comparatives. ${ }^{23}$

- Items with /e:/. drehen (OHG drājen, drāen, MHG drcejen), leer (OHG lāri, MHG laere), schwer (OHG swāri, MHG swoere), etc.

- Items with the weak $i$-umlaut of $\mathrm{OHG} / \mathrm{a} /$ to $/ \mathfrak{x} /$ and subsequent lengthening of $/ \varepsilon /$, exhibit /ع:/. Examples: Ähre (OHG ahir, MHG äher), erwähnen (*wahanjan > OHG [gi]wahanen, MHG [ge]wähenen), vermählen (OHG mahal[j]en, MHG mähelen), etc.

- The original plurals Träne (MHG pl. trähene, OHG trahani) and Zähre 'Träne' (MHG pl. zähere, $\mathrm{OHG}$ zahari) belong here.

- The word ähnlich (OHG analīh) belongs here, since it has /æ/, caused by an $i$-vowel in the second following syllable (MHG änelich, enelich), as well as retained /a/, because the $i$-vowel in the ending līh may or may not cause umlaut (MHG anelich). ${ }^{24}$

\footnotetext{
${ }^{22}$ In Present Standard German the occurrence of $i$-umlaut in the comparative of adjectives is by no means the rule. It normally occurs in these monosyllables: alt, arg, arm, dumm, grob, groß, hart, hoch, jung, kalt, klug, krank, kurz, lang, nah, scharf, schwach, schwarz, stark, warm. In other cases there is variation between forms with and without umlaut: bang, blass, fromm, glatt, karg, krumm, nass, rot, schmal, and the disyllabic gesund. Numerous other cases form the comparative without $i$-umlaut. Cf. Dudenredaktion (2009: 367f.), where the "colloquial" doof should be added to the list of adjectives which exhibit variation between forms with and without umlaut.

${ }^{23} \mathrm{Cf}$. schmäler (above) and the preceding footnote.

${ }^{24}$ No need, therefore, to assume (with Sanders 1972: 53) that ähnlich should be explained as a blending of the original form with MHG enelich 'grandfatherly', literally 'forefatherly'.
} 
- Instances like Mädchen (OHG magadīn, MHG mägedīn), Väterchen (OHG faterlīn, MHG väterlīn), and täglich (OHG tagalīh, MHG tägelich) also belong here, the first two with suffix substitution (OHG -ihhī[n], MHG -ichin, -chen). ${ }^{25}$

- Some instances with an expected umlaut $/ \mathrm{a} />/ \mathfrak{x} /$ due to $/ \mathrm{i} /$ in the third syllables, such as Frevel (OHG fravali, MHG frävele), Erz (OHG aruzzi, MHG ärze), and Pferd (OHG pfarafrit, MHG pfärt), are inconclusive with regard to a possible lengthening of $/ \varepsilon /$ to /e:/, because of variants with assimilated /i/ in the second syllable, such as OHG fravili $>$ frevil (MHG frevele), OHG arizzi > erizzi (MHG erze), and pfarifrit > pferit (MHG pfert), which exhibit the strong $i$-umlaut of $\mathrm{OHG} / \mathrm{a} /$ to /e/. ${ }^{26}$

- The word gemächlich (OHG gimahlīh, MHG gemechlich), which now varies between $/ \varepsilon$ :/ and $/ \varepsilon /$, has a long vowel on the analogy of the formerly synonymous gemach, and the same applies to allmählich (OHG [gi]mahlīh, MHG almechlich), which may reflect a variant with loss of $/ \mathrm{x} /$ before syllable-initial $/ 1 / .^{27}$

- In instances like Hähne (OHG hanun, MHG hanen) the generalized marker of the plural number / $\varepsilon$ : / has replaced /a:/ by lengthening of/a/ (Hahn < OHG hano, MHG hane). Cf. Räte (OHG rāti, MHG raete) - Rat (OHG MHG rāt), which exhibits a regularly developed $/ \varepsilon: /$.

- Items with $\mathrm{OHG} / \varepsilon /$ may have subsequent lengthening to either / $\varepsilon$ :/ or /e:/. Examples:

- Bär (OHG bero, MHG ber-), gebären (OHG giberan, MHG geberen), währen (OHG werēn, MHG weren), etc. ${ }^{28}$

- Kehl (OHG kela, MHG kel-), leben (OHG lebēn, MHG leben), nehmen (OHG neman, MHG nemen), Wert (OHG werd, MHG wert), etc.

Now, if we leave aside for a moment all the instances in which various types of analogy have been at work, we may sum up the situation as follows:

- $\mathrm{OHG}$ MHG /e:/ continues as PSG/e:/;

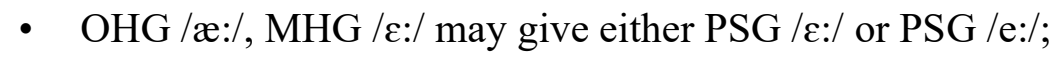

- $\quad$ OHG MHG /e/ with subsequent lengthening becomes PSG/e:/;

- $\mathrm{OHG} / \mathfrak{m} /$ with subsequent lengthening becomes PSG $/ \varepsilon: / ;$

- $\mathrm{OHG} / \varepsilon /$ with subsequent lengthening may give either PSG / $\varepsilon$ :/ or PSG /e:/.

On the basis of this state of affairs we may present a schematic picture of the relevant changes.

In certain types of speech belonging to the Central German and Upper German (East Franconian) areas MHG / $\varepsilon$ :/ from OHG /æ:/ merged with the reflex of OHG MHG /e:/, which

\footnotetext{
${ }^{25}$ No need, therefore, to explain (with Sanders 1972: 54) the long vowel / $\varepsilon$ :/ in these forms on the analogy of Magd (OHG magad, MHG maget), Vater (OHG fater, MHG vater), Tag (OHG, MHG tag-).

${ }^{26}$ But Erz may also have OHG /e/ from a variant *arit- beside *arut- (MHG arze).

${ }^{27}$ Cf. Michels (1921: 155, fn. 3), who records Alemannic rîlîch for rîchlîch. Sanders, who assumes only /ع/ in gemächlich, explains allmählich as showing misunderstanding of $\langle\mathrm{h}\rangle$ as a vowel-length sign (1972: 54, fn. 64). Hinderling (1978: 41) does not explain allmählich, but seems to assume that its short vowel was OHG /e/ (strong $i$-umlaut of /a/), though /æ/ (weak $i$-umlaut of $/ \mathrm{a} /$ ) is more likely before $/ \mathrm{h} /$.

${ }^{28}$ Sanders (1972: 53) lists these and other words (cf. Moulton 1961: 34) and discusses possible explanations (influence of $/ \mathrm{r} /$, related forms with $/ \overline{\mathrm{a}} /$, orthographic differentiation), but he does not seem inclined to consider them as exceptions. Hinderling (1978: 41) seems to assume OHG /e/ (strong $i$-umlaut of /a/) in schwären (OHG sweran, MHG swer [e]n 'schmerzen, schwellen'). But this word belongs here, since its original short vowel was $/ \varepsilon /$.
} 
continues as PSG /e:/ (as in Zeh, mehr, Ehre). However, in other types of speech belonging to the Upper (but in part also to the Central) German area MHG / $\varepsilon$ :/ from OHG /æ:/ has been preserved to the present day as $/ \varepsilon: /$, which varies phonetically between [ $\varepsilon:]$ and [æ:] (as in $z \ddot{a} h$, Mär) - cf. 2.1 above.

The lengthened reflex of OHG /e/ merged with /e:/ (as in Beere, wehren), but the lengthening

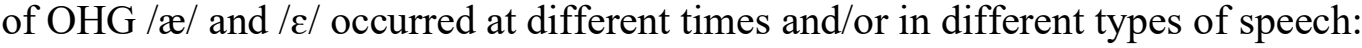

- the lengthened reflex of OHG/æ/ merged only with /ع:/ (as in Ähre), a change that may be assumed to have occurred before the raising of $/ æ /$ to $/ \varepsilon /$;

- the lengthened reflex of $\mathrm{OHG} / \varepsilon /$ merged with $/ \varepsilon$ :/ in certain types of speech belonging to the Central German and Upper German (East Franconian) areas; this change must have occurred before the merger of / / / and /e/. Examples: Bär, währen, etc. But in other types of speech belonging to the Upper (but in part also to the Central) German area the lengthened reflex of $\mathrm{OHG} / \varepsilon /$ merged with /e:/; this change must have occurred after the merger of $/ \varepsilon /$ and /e/. Examples: leben, Wert, etc. - cf. 2.1 above.

The above analysis based on etymological criteria allows us to arrive at two conclusions. The

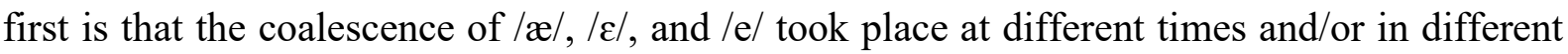
types of speech in late Old or early Middle High German. Further, that the reduced incidence of $/ \varepsilon /$ and /e/ caused by lengthening (chiefly in an open syllable and before $/ \mathrm{r} /$ plus consonant) favoured the subsequent merger of $/ \mathrm{e} /$ and $/ \varepsilon /$. The resulting $/ \varepsilon /$ was then accepted by the New High German "Schriftsprache" and eventually preserved by Present Standard German. Examples with older /æ/, /ع/, and /e/ are Geschlecht (OHG gislahti, MHG geslehte, geslähte), Recht (OHG recht, MHG recht), and fest (OHG festi, MHG feste).

The second conclusion is that the merger of $/ \varepsilon$ :/ and /e:/ was by no means generalized, so that $/ \varepsilon: /$ preserved its identity, at least in certain types of regional speech. This is indicated by the following considerations:

- Words like Mär, säen, träge, zäh can be shown to exhibit a phonologically developed /ع:/.29

- OHG MHG /e:/ has never become /ع:/ (cf. Hinderling 1978: 38). Examples: Ehre, mehr, See, Zeh[e], etc.

- No analogical formations like (du) färst (MHG ferest), Hähne (MHG hanen), etc. would have been possible without the existence of a phoneme $/ \varepsilon$ : / in the types of speech in which they were created. The morphologization of umlaut may occur also in the pre-literary stages of a language and is attested also in recent dialects, ${ }^{30}$ where it cannot be explained by having recourse to the influence of the orthography.

These conclusions are to a certain extent corroborated by the dialectal evidence presented and discussed by Hinderling (1978: esp. 42-61), who argues that the various reflexes of the $e$ vowels in recent dialects suggest that the development of $\mathrm{NHG} / \varepsilon$ :/ belongs to historical phonology and not merely to historical orthography.

\footnotetext{
${ }^{29}$ Sanders (1972: 44f.) rightly observes that analogy cannot be invoked for such instances as Märchen, dim. of Mär (OHG māri, MHG maere) and Mähre (OHG mariha, MHG märhe), since no related forms with /a:/ can be found.

${ }^{30}$ For the morphologization of umlaut in recent German dialects cf. Hinderling (1978: 42-61).
} 
To assume that / $\varepsilon$ :/ simply merged with /e:/ in all the types of speech that contributed to the formation of the New High German "Schriftsprache" amounts to ignoring the etymological evidence and to forgetting that the transition from Middle to New High German was a complex process involving phonological compromises between different regional features, in our case between Low and Central German /e:/ and Central and Upper German /ع:/.31

True, the acceptance of the distinction between the two phonemes in general usage was certainly encouraged by morphological/etymological considerations which led to the use of 〈ä〉 (and consequently of / $\varepsilon: /)$ in words with original /e:/ (as in zählen, MHG zelen) and forms with earlier /a:/ (as in Hähne, MHG hanen). But the fact that these modifications were due to prescriptive tendencies promoted by grammarians, printers, and linguistic societies does not imply that the distinction between $/ \varepsilon: /$ and /e:/ was invented, since it occurred in regional types of speech that made their way into the New High German "Schriftsprache".

A possible objection to the acceptance of the phoneme $/ \varepsilon$ :/ as resulting from phonological developments is that recent dialects which preserve the distinction between / $\varepsilon$ :/ and /e:/ do not agree with standard usage with regard to the distribution of the two phonemes. But the fact that Central and Upper German areas may have, for example, / $\varepsilon$ :/ in leben but /e:/ in heben and legen can only confirm the phonological origin of $/ \varepsilon$ :/ as opposed to /e:/. In these types of speech $\mathrm{OHG} / \varepsilon /$ with subsequent lengthening (OHG lebēn, weban) merged with / $\varepsilon:$ - whereas in others it merged with /e:/ (cf. above) - and this phoneme was kept apart from /e:/ derived from OHG le/ with subsequent lengthening (MHG heben, OHG heffen; OHG legen < *lagjan). Regional usage cannot be expected to agree with standard usage, which is often the result of a complex process of linguistic levelling.

Another possible objection to the acceptance of the phoneme $/ \varepsilon$ :/ as resulting from phonological developments is that certain speakers of Standard German who normally keep / $\varepsilon: /$ and /e:/ apart occasionally fail to make the distinction. But this is irrelevant, since it is a well-known fact that a normal (or indeed intense) intercourse with speakers who use different variants (in this case /e:/ in words with "long $\ddot{a}$ ") may obviously result in occasional confusion or even in the acceptance of a specific variant.

We may then conclude that the vowel / $\varepsilon$ :/ is the result of phonological developments and that its incidence and distribution reflect a complex process of linguistic levelling influenced by prescriptive tendencies. This phoneme is now preserved in some varieties of Standard German and, generally, not only as the name of the letter $\ddot{a}$, but also as a means of distinguishing otherwise homophonous words like Ähre and Ehre, währen and wehren, zäh and Zeh, etc.

\section{Conclusions}

A critical analysis of the available material has shed light on the phonological history of various vocalic phonemes and in particular of $/ \varepsilon /$ and /e/ as well as of $/ \varepsilon: /$ and /e:/. The changes that affected the two pairs led to different results in the New High German "Schriftsprache". The developments connected with these vowels corroborate, among other things, the view that today's / $:$ :/ beside /e:/ in words with "long $\ddot{a}$ " (e. g. spät) is not an artificial vowel based on the

31 Cf. Sanders (1972: 55), who speaks of linguistic levelling (“Sprachausgleich”) between regional variants. 
spelling, but a historical variant with a phonological history behind it and that its incidence and distribution reflect a complex process of linguistic levelling influenced by prescriptive tendencies.

\section{References}

AWB: Althochdeutsches Wörterbuch (1952-). Auf Grund der von Elias von Steinmeyer hinterlassenen Sammlungen im Auftrag der Sächsischen Akademie der Wissenschaften zu Leipzig. Bearbeitet und herausgegeben von Elisabeth Karg-Gasterstädt und Theodor Frings. Leipzig: SAW.

Becker, Thomas (2012): Einführung in die Phonetik und Phonologie des Deutschen. Darmstadt: Wissenschaftliche Buchgesellschaft.

Braune, Wilhelm/Heidermanns, Frank (2018): Althochdeutsche Grammatik I: Laut- und Formenlehre. 16. Auflage, neu bearbeitet von Frank Heidermanns. Berlin/Boston: de Gruyter.

Cercignani, Fausto (forthcoming): "On the Germanic and Old High German distance assimilation changes". Atti del Sodalizio Glottologico Milanese.

Dudenredaktion (2009): Die Grammatik (Duden - Deutsche Sprache in 12 Bänden; 4). Berlin: Bibliographisches Institut.

FNHDG: Ebert, Robert Peter et al. (1993): Frühneuhochdeutsche Grammatik. Tübingen: Niemeyer.

Garbe, Burckhard (2000): "Phonetik und Phonologie, Graphetik und Graphemik des Neuhochdeutschen seit dem 17. Jahrhundert”. In: Besch, Werner et al. (eds.): Sprachgeschichte. Ein Handbuch zur Geschichte der deutschen Sprache und ihrer Erforschung Vol II. Berlin/New York, de Gruyter: 1765-1782.

DWB: Deutsches Wörterbuch von Jacob und Wilhelm Grimm. 16 Bde in 32 Teilbänden. Leipzig 1854-1961. Quellenverzeichnis Leipzig 1971. woerterbuchnetz.de/cgi-bin/ WBNetz/wbgui_py?sigle=DWB [05.11.2021].

woerterbuchnetz.de/cgi-bin/WBNetz/wbgui_py?sigle=DWB

Hinderling, Robert (1978): "Das Phonem nhd. /ä:/ im Lichte von Sprachgeschichte und Dialektologie". In: Hinderling, Robert/Weibel, Viktor (eds.): Fimfchustim. Festschrift für Stefan Sonderegger zum 50. Geburtstag. Bayreuth, Lehrstuhl für Deutsche Sprachwissenschaft: 29-61

Klein, Thomas (2021): “Gab es eine mitteldeutsche Monophthongierung?". Sprachwissenschaft 46/3: 267-314.

Kluge, Friedrich/Seebold, Elmar (2011): Etymologisches Wörterbuch der deutschen Sprache. Von Friedrich Kluge, bearbeitet von Elmar Seebold. 25. Aufl. Berlin/Boston: de Gruyter.

Köbler, Gerhard (2014): Althochdeutsches Wörterbuch. koeblergerhard.de/ahdwbhin.html [12.02.2022].

KSW: Klein, Thomas/Solms, Hans-Joachim/Wegera, Klaus-Peter (2018): Mittelhochdeutsche Grammatik II.1. Berlin/Boston: de Gruyter.

Michels, Victor (1921): Mittelhochdeutsches Elementarbuch. Heidelberg: Winter.

Moulton, William G. (1961): "Zur Geschichte des deutschen Vokalsystems". Beiträge zur Geschichte der deutschen Sprache und Literatur 83: 1-35. 
MWB: MWB online. Mittelhochdeutsches Wörterbuch. Mainzer Akademie der Wissenschaften und der Literatur. Akademie der Wissenschaften $\mathrm{zu}$ Göttingen. mhdwb-online.de [12.02.2022].

Paul, Hermann/Klein, Thomas et al. (2007): Mittelhochdeutsche Grammatik. Neu bearbeitet von Klein, Thomas et al. Tübingen: Niemeyer.

Penzl, Herbert (1974): “Zur Entstehung der frühneuhochdeutschen Diphthongierung". In: Besch, Werner et al. (eds.): Studien zur deutschen Literatur und Sprache des Mittelalters. Berlin, Schmidt: $345-357$.

Reichmann, Oskar (2000): “Die Diagliederung des Frühneuhochdeutschen”. In: Besch, Werner et al. (eds.): Sprachgeschichte: Ein Handbuch zur Geschichte der deutschen Sprache und ihrer Erforschung Vol II. Berlin/New York, de Gruyter: 1623-1646.

Russ, Charles V. J. (ed.) (1990): The Dialects of Modern German: A Linguistic Survey. London: Routledge.

Sanders, Willy (1972): “Hochdeutsch /ä/ - 'Ghostphonem' Oder Sprachphänomen?”. Zeitschrift für Dialektologie und Linguistik 39/1: 37-58.

Schirmunski, Viktor M. (1962): Deutsche Mundartkunde. Vergleichende Laut- und Formenlehre der deutschen Mundarten. Aus dem Russischen übersetzt und wissenschaftlich bearbeitet von Wolfgang Fleischer. Berlin: Akademie Verlag.

Simmler, Franz (2000): "Phonetik und Phonologie, Graphetik und Graphemik des Mittelhochdeutschen”. In: Besch, Werner et al. (eds.): Sprachgeschichte: Ein Handbuch zur Geschichte der deutschen Sprache und ihrer Erforschung Vol II. Berlin/New York, de Gruyter: 13201331.

Szulc, Aleksander (1969): Abriss der diachronischen deutschen Grammatik, Teil I: Das Lautsystem. Halle: Niemeyer.

Wiesinger, Peter (1970): Phonetisch-phonologische Untersuchungen zur Vokalentwicklung in den deutschen Dialekten II. Berlin/NewYork: de Gruyter.

Wiesinger, Peter (2003): "Systementwicklungen des Deutschen im Bereich des Vokalismus". In: Besch, Werner et al. (eds.): Sprachgeschichte: Ein Handbuch zur Geschichte der deutschen Sprache und ihrer Erforschung Vol. III. Berlin/New York, de Gruyter: 2440-2461.

Wolf, Norbert Richard (2000): "Phonetik und Phonologie, Graphetik und Graphemik des Frühneuhochdeutschen”. In: Besch, Werner et al. (eds.): Sprachgeschichte: Ein Handbuch zur Geschichte der deutschen Sprache und ihrer Erforschung Vol II. Berlin/New York, de Gruyter: $1527-1542$. 